\title{
TRANSPORTATION REGULATION AND THE DEPARTMENT OF COMMERCE
}

\section{Q. DIGKERMAN WILLIAMST}

Governuent reorganization is in the air. In recent years President Truman submitted to Congress numerous plans in accordance with powers granted him by the Reorganization Act of $1949^{1}$ and, generally, with the recommendations of the Committee on Organization of the Executive Branch. of which former President Hoover was chairman. Congress approved most of these plans. In February of this year President Eisenhower appointed a new Committee on Organization headed by Nelson Rockefeller. And in an act signed by the President on February 11, Congress renewed for two years the President's reorganization powers. ${ }^{2}$

Among the more interesting reorganization proposals is that made by Dr. Samuel P. Huntington in his recent article in this JournaL, "The Marasmus of the ICC: The Commission, the Railroads, and the Public Interest."3 After criticizing the Commission adversely, Dr. Huntington offers as a solution the abolition of the Commission and the transfer of its powers to three separate commissions dealing respectively with rail, water, and highway transportation, all to be within the Department of Commerce and subject to the policy guidance of the Secretary of Commerce. Dr. Huntington indicates his expectation that the Secretary of Commerce, whose duties are manifold, would rely in the discharge of this responsibility largely on the advice of the Under Secretary of Commerce for Transportation, an office created by Reorganization Plan No. 21 of 1950, hereinafter referred to as "Plan 21."

Basically what Dr. Huntington would do is to substitute: (1) an agency of the executive branch for a quasi-legislative, quasi-judicial body; (2) a single policy-making officer for a group of officers; and (3) an officer whose tenure is at the pleasure of the President of the United States for officers with tenure established by law and who, in practice, hold office for rather long terms.

The validity of Dr. Huntington's criticism of the Commission has been analyzed by Dr. Charles S. Morgan of the Commission staff. The purpose

iMember, New York Bar; formerly General Counsel, United States Department of Commerce.

1. 63 StAT. 203 (1949), 5 U.S.C. §133z (Supp. 1952).

2. Pub. L. No. 3, 83d Cong., 1st Sess. (Feb. 11, 1953).

3. 61 YALE L.J. 467 (1952) (hereinafter cited as Huntington). Dr. Huntington's proposed reorganization is found $i d$. at $508-09$.

4. 64 StAT. 1273 (1950), 46 U.S.C. \$1111 note (Supp. 1952).

5. A Critique of "The Marasmus of the ICC: The Commission, the Kailroads, asd the Public Interest," 62 YALE L.J. 171 (Jan., 1953). The author is Chief Carrier Analyst, Bureau of Transport Economics and Statistics, ICC. 
here is to comment on the remedy proposed by Dr. Huntington. It is a proposal of a kind made from time to time and on each occasion supported by the same general arguments. The present writer will draw on his observations as General Counsel of the Department of Commerce for the past two years.

\section{Plan 21 as a Precedent}

Dr. Huntington finds a "pattern" for his proposal in the "recent reorganization of the Maritime Commission. ..." His three commissions should be, he says, "in a position similar to that of the Maritime Board and subject to the same policy guidance of the Secretary."

"Placing the separate commissions in the Department of Commerce would remove the need for an appellate commission since it would be up to the Secretary to define general transportation policies and to resolve differences among the commissions.... The logic of the situation requires the unification of all transportation policy responsibility in the Department of Commerce."s

The "recent reorganization" to which Dr. Huntington refers is that effected by Plan 21 . The Maritime Commission was thereby abolished. Its administrative duties were transferred to the Maritime Administration, its regulatory and subsidy powers to the Federal Maritime Board. Both were placed within the Department of Commerce. ${ }^{9}$

The aptness of the analogy between the reorganization proposed by Dr. Huntington and that accomplished by Plan 21, his use of the words "pattern," "same," and "similar," his implication that what he wants is merely that the Department of Commerce do more of what it is doing now, are very much open to question.

Preliminarily, we may note a difference in the Secretary's area of policy responsibility. No limit is specified by Dr. Huntington. But according to the explanatory message of the President of March 13, 1950, accompanying the submission of Plan 21 to Congress, the Secretary's function is "over-all transportation policy zeithin the executive branch." ${ }^{10}$ The use of the expression "within the executive branch" made clear the intention of the President in no way to supersede or interfere with the authority of Congress and the regulatory agencies with respect to transportation policy.

The omission of any such limiting phrase from Dr. Huntington's recommendation may or may not be of significance. In another context stch a limitation might be regarded as something that "goes without saying." Never-

6. Huntington, p. 508.

7. Id. at pp. 508-09 (emphasis added).

8. Id. at p. 509 n. 185 .

9. As already mentioned, the Plan also created the office of Under Secretary of Commerce for Transportation.

10. H.R. Doc. No. 526, 81st Cong., 2 d Sess. 5 (1950) (emphasis added). 
theless, in an article urging a large expansion of the Secretary's powers, more precision would have been welcome.

A more important discrepancy between the maritime reorganization and $\mathrm{Dr}$. Huntington's proposal is found in the express provision of Plan 21 (Section 106), that in the exercise of its regulatory functions the Federal Maritime Board shall be "independent of the Secretary of Commerce."11 This provision was stressed in the explanatory message of the President. But it is against the ICC's exercise of regulatory functions that Dr. Huntington so bitterly and so extensively complains, and it is the supervision of those functions that he proposes to assign to the Secretary.

It is true that in the exercise of its subsidy functions the Board, under Plan 21 , is to "be guided by the general policies of the Secretary of Commerce" (Section 107). Presumably it is this provision which has led Dr. Huntington to the apparent belief that the Secretary is already acting as an appellate tribunal. But Section 105(1) of Plan 21 expressly provides that the action of the Board in subsidy matters "shall be final." And in his testimony before Congress at the hearings when Plan 21 was under consideration. Secretary Sawyer forcefully and unequivocally repudiated the thought that the Secretary of Commerce would thereby be authorized to review the Board's action in subsidy matters. ${ }^{12}$ In fact, at these hearings all that the policy guidance seemed to amount to was that the Board, in awarding subsidies, would act within the scope of the trade routes determined by the Secretary under Section 211 of the Merchant Marine Act, 1936. ${ }^{13}$

Mr. Sawyer, a most energetic public officer, was Secretary of Commerce from the effective date of Plan 21, May 24, 1950, until his retirement on January 20,1953, upon the change in administration. During that period of almost three years he did not adopt a single "policy," if we conceive of policy, as Dr. Huntington seems to. as a principle in the nature of a statute or directive to control the actions of the Board. He made no change in the trade routes previously established by the Maritime Commission. In fact, his only public activity in the field of maritime subsidy was his vigorous opposition to the demand of the Comptroller General that the government re-

11. Huntington, p. $467 \mathrm{n.1}$, classifying the Federal Maritime Beard as an ageney "primarily engaged in the regulation of carriers" and locating it within the Department of Commerce, is therefore only technically accurate. In the respect with which Dr. Huntington is concerned, vis., regulation, it is, in effect, outside the Department.

12. Hearings before Senate Committec on Expenditures in the Excentian Defartments on S. Res. 265, 81st Cong., 2 d Sess. (1950). Secretary Sawyer testified in part: "I should like to make it clear that under the plan the Secretary has no authority either to award a subsidy or to direct the action of the Buard on a subsidy applieatiun." Id. at 41. "[The Secretary of Commerce] cannot only not override [the Board] ; he cannot direst them in the first place." Id. at H. The discussion of trade routes is found id. at 40 . Despits these disclaimers, Plan 21 lays a foundation for Cummerce Department extralsgal influence over the FMIE as developed at page 571 infra, an influnce which Sucretary Sawyur did not exert.

13. 49 SтAт. 1989 (1936), 46 L.S.C. \$1121 (1946). See Hcarimys, susra nute 12. 
pudiate the construction differential subsidy contract for the S.S. United States. ${ }^{14}$

In conclusion, Dr. Huntington's seeming intimation that all he is proposing is that the Secretary and Department of Commerce do more of what they are already doing cannot be accepted. His proposal should be recognized for what it is, a novel and drastic reorganization of transportation regulation. That of course is not a reason for its rejection. Let us consider it on its merits.

\section{Theoretical and Practical Difficulties with Commerce Department Regulation}

Perhaps the most arresting feature of Dr. Huntington's proposal is its aggrandizement of the executive branch. As already noted, Dr. Huntington is somewhat vague in his use of the words "transportation policy." Presumably, he does not deny that rate-making and regulation are legislative in character. $\mathrm{He}$ does not, we must assume, propose that Congress abdicate its powers, but rather that the delegation of them run to the executive branch instead of to the ICC as at present. It would thus be only such questions of policy as arise in the course of the exercise of these delegated powers that the Department of Commerce would decide.

It is to be recognized that this would probably not be unconstitutional. Much, if not most, congressional delegation is to the executive branch. The executive exercise of quasi-legislative powers has frequently been sustained. ${ }^{15}$ It is true that the most extreme examples are in the field of foreign affairs, an area deemed a special province of the President. ${ }^{10}$ However, in Swayne \& Hoyt, Ltd. v. United States ${ }^{17}$ the Supreme Court sustained the delegation to the Secretary of Commerce of the power to regulate rates under the Shipping Act of 1916, a power previously vested in the Shipping Board. The rates involved were inter-coastal. The only apparent distinction between the delegation at issue in Swayne \& Hoyt and that proposed by Dr. Huntington is one of degree..$^{18}$

14. Letter to Hon. John F. Shelley, Chairman of a subcommittee of the Committee on Merchant Marine and Fisheries of the House of Representatives, in Department of Commerce News Release, June 23, 1952.

15. E.g., Marshall Field \& Co. v. Clark, 143 U.S. 649 (1891); Buttfield v. Stranahan, 192 U.S. 470 (1904); Union Bridge Co. v. United States, 204 U.S. 364 (1907); United States v. Rock Royal Cooperative, 307 U.S. 533 (1939).

16. See United States v. Curtiss Wright Export Corp., 299 U.S. 304 (1936); Chicago \& So. A.L. v. Waterman S.S. Corp., 333 U.S. 103 (1948); Pan American Airways v. CAB, 121 F.2d 810 (2d Cir. 1941) (the two latter cases uphold the authority of the President over foreign air certificates provided in $\S 801$ of the Civil Aeronautics Act, 52 STAT. 973 (1938), 49 U.S.C. $\$ 199$ (1946), an authority distinctly legislative in character).

17. 300 U.S. 297 (1937).

18. One is inclined to wonder why Dr. Huntington did not choose as his "pattern" the seemingly" more similar delegation of regulatory functions to the Secretary of Commerce effected by $\S 12$ of Exec. Order No. 6166 (June 10, 1933), rather than "the recent 
Assuming, therefore, that the grant can be validly effected, should the Department of Commerce have such powers? The answer to this question involves serious problems of government organization.

In the first place, it is contrary to the theory of the separation of powers for the legislative body to delegate its functions to the executive branch if not clearly necessary. It is to be remembered that the original Act to Regulate Commerce to some extent placed the ICC within the Department of the Interior, ${ }^{19}$ but the Commission was made wholly independent soon thereafter. ${ }^{29}$ At one time the Comptroller of the Treasury, an officer of the Department of the Treasury, audited the accounts of the executive branch. ${ }^{21}$ Subsequently Congress, recognizing that audit was incidental to the legislative power of appropriation, transferred the function to the Comptroller General. 2 Mention has already been made of the abolition of the maritime rate-maling powers enjoyed by the Secretary of Commerce between 1933 and 1936 and the solicitude of the President-evidenced in the language and explanation of Plan 21 -for Federal Maritime Board independence in the exercise of its regulatory function.

A grant of these powers to the Department of Commerce would raise many difficulties. One man is head and in virtually complete control of the Department of Commerce. ${ }^{23}$ The variety of personalities who have occupied that post in recent years indicates a strong probability that there would have been rapid and violent changes in transportation policy if that had been a Departmental responsibility. That would have happened when Jesse Jones succeeded Harry Hopkins? Or when Jones was turned out in favor of Henry A. Wallace? Or when Charles Sawyer took over from WT. Averell Harriman? Une would never use the word monotonous in describing the succession of Secretaries of Commerce.

The Under Secretary of Commerce for Transportation is intended by Plan 21 to be the Secretary's principal adviser on transportation. The occupants of this post have been able and forceful men but also most varied in background, and the turnover has been rapid. The first appointee was General Philip B. Fleming, who had had a distinguished career as a soldier and administrator. His transportation experience had been exclusively maritime.2i He resigned because of ill health in May, 1951, after a little less than a year

reorganization of the Miaritime Commission." Can the reasun be that the earlier delegation proved so unsatisfactory that it was promptly repealed by the Merchant Marine Act of 1936? (49 STAт. 1985 (1936), 46 U.S.C. $\$ 1101$ (1946)).

19. 24 Stat. $386-7, \S \S 18,21$ (1887).

20. 25 SтAт. 855 (1889).

21. 28 Stat. 206 (1894).

22. Section 301, Budget and Accounting Act, 192142 ST.1T. 23 (1921), 31 U.S.C. $\$ 41$ (1946).

23. 64 Stat. 1263 (1950), 5 U.S.C. $\$ 133 z-15$ note (Supp. 1952) (Reorganization Plan No. 5 of 1950).

24. But even that was slight. 
in office. He was succeeded by Delos W. Rentzel, who had served brilliantly as Civil Aeronautics Administrator and Chairman of the Civil Aeronautics Board. Mr. Rentzel resigned in November, 1951, to accept a position in private industry. The office was not filled until May, 1952. During the interim, Philip A. Hollar, Deputy Under Secretary, advised the Secretary. Apart from his government service, Mr. Hollar had been employed in the railroad and railroad equipment industries. Jack Garrett Scott became Under Secretary in May, 1952. He is a lawyer and was general counsel to the National Associrtion of Bus Operators at the time of his appointment. Mr. Scott resigned in January, 1953, because of the change in administration.

Although rigidity is not a desideratum in transportation policy, the uncertainty that would thus have occurred had Dr. Huntington's plan been in effect in recent years is likewise to be avoided. The organization of the ICC, consisting as it does of eleven members with staggered terms of seven years, ${ }^{20}$ provides a large measure of stability with constant opportunity for the injection of new thinking. The number of commissioners assures that every decision will represent a composite of experience in a variety of associations and endeavors.

An additional objection lies in the essentially political character of the Secretary of Commerce and the Under Secretary for Transportation. They cannot close their doors to $e x$ parte callers nor insist that stenographic minutes be taken of every conversation. Holding office at the pleasure of the President, they are subject to his orders, and he very properly is concerned with getting votes. Pressures of this sort are much more remotely exerted on the ICC, which, as Dr. Huntington correctly says, nevertheless requires political support from some source. The good will of the President is an obvious prerequisite to appointment of the individual commissioners, ${ }^{20}$ and the Commission as a whole requires congressional appropriations if it is to perform its duties. These requirements mean that while the Commission cannot carry on in an ivory tower, it does remain free of the demands made upon the lieutenants of the President.

The transfer of regulatory powers to the Department of Commerce would also be inconsistent with the transportation responsibilities of other agencies

25. 24 Stat. 383 (1887), as amended, 49 U.S.C. $\$ 11$ (1946).

26. In view of the special interest of the Department of Commerce in transportation, the President, as a matter of routine, might well look to the Secretary for investigation and recommendation concerning appointments to the regulatory agencies, as he now looks to the Attorney General with respect to judicial appointments. So far as the writer is aware, the President has hitherto never done so with respect to the ICC, and only occasionally as to the $C A B$ and FMB (including its predecessors). In addition to providing an orderly procedure, such a practice would assure the Secretary a somewhat greater voice in transportation policy in a manner consistent with the traditional separation of powers. A possible objection is that his influence would thereby become excessive in view of the short terms of office of the members of the CAB and FMB (five and four years, respectively). An obvious remedy, and it is a measure that deserves consideration in any event, would be to lengthen those terms. 
of the executive branch. The Department of Agriculture is required to protect the rates on agricultural products and is authorized for that purpose to appear before regulatory agencies; the General Services Administration, and in some instances the Department of Defense, have similar commissions on behalf of government traffic; price control agencies have been allowed to intervene in rate cases; the Department of Justice from time to time finds its programs involved; mail rate cases before the $\mathrm{CAB}$ are contested by the Departments of the Post Office and of the Interior. ${ }^{27}$ Although there is probably no inherent reason why the Department of Commerce could not be authorized to decide matters presented to it by other agencies of the executive branch. the necessity for rejecting their contentions, at least on occasion, contains the seeds of embarrassment. Certainly such an organizational scheme would not be conducive to harmony.

Dr. Huntington cites an article by the Assistant Solicitor General, Robert $\mathrm{L}$. Stern, ${ }^{28}$ to show the present extent of legal controversy between the $\mathrm{IC} \mathrm{C}^{\circ}$ and other government agencies. But Mr. Stern also points out that when another government agency differs from the Department of Justice in a cuurt case, "determination by the judiciary is often more satisfactory than an effort by" the Department of Justice to force its own views on the disagreeing agency by refusing to present the agency's position to the courts. " 9 "So both positions are presented and the court decides who is right. In the same way the executive agencies with transportation responsibilities would presumably prefer to take their chances with the ICC or other regulatory body rather than assume the risk of an adverse determination by the Department of Commerce. For the Secretary of Agriculture or the Attorney General to be publicly overruled by the Secretary of Commerce would be humiliating: in the other hand, cabinet officers accept more or less philosophically the rejectiun of their views by the legislative and also the judicial branch.

Among the experts on the capacity of the Department of Commerce to undertake the functions Dr. Huntington proposes to give it, must be included the Secretary of Commerce and the Under Secretary for Transportation.

27. Agriculture: 52 ST.1T. 36 (193\$), 7 U.S.C. $\$ 1291(b)$ (1946); General Services Administration and Department of Defense: 63 Srir. 383 (1949), 40 U.S.C. $\$ 4 \$ 1$ (a) (4) (Supp. 1952); Office of Price Stabilization: Defcnse Pruduction Act, Title IV, \$402(d) (3) (v), 64 Stat. $\$ 06$ (1950), 50 U.S.C. App. $\$ 2102$ (Supp. 1952); Post Ofice and Interior: Civil Aeronautics Act of 193\$, $\$ 406,52$ StnT. $99 \$$ (193\$), 49 U.S.C. $\$ 486$ (1946) (Interior acts on behalf of Hawaii and Alaslia, dealt with by subsection (e)). See Huntington, pp. 486-7. Whether so many executive agencies should have transportation responsibilities, and how active they should be, are controversial questions touched upron in note 45 infra.

28. "Inconsistency" in Government Litigation, $65 \mathrm{HARv}$. L. KEv. 762 (1951), citcd at Huntington, p. 506 n.178.

29. Stern, sipra note 28 , at 769 .

30. In fact so humiliating that the Secretary of Commerce would have to be a marvel of detachment to avoid being influenced by considerations of interdepartmental relations and similar factors extraneous to the merits. 
Dr. Morgan has cited Secretary Sawyer's dictum in a speech made in April, 1952 (the same month in which Dr. Huntington's article was published), entitled "The Government's Role in Transportation." "Regulatory activity," the Secretary said, "should be exercised by independent agencies." "Secretary Sawyer "assured" the Senate Committee on Appropriations "time and again" that there was no "purpose" on the part of the Commerce Department to "take over" regulatory functions. ${ }^{32}$ Under Secretary Scott gave assurances to the same effect. ${ }^{33}$ The Commerce Department order specifying the duties of the Under Secretary for Transportation cautions: "No provision of this order shall be construed as empowering or directing the Under Secretary for Transportation to assume or perform regulatory functions or operating functions in the field of transportation." ${ }^{34}$

These are the most recent expressions on this subject by officers of the Commerce Department. ${ }^{35}$ Their point of view is fortified by the absence of any demand by former Secretaries of Commerce for regulatory functions. It is of special interest that former President Hoover, who enjoyed the longest tenure of any Secretary of Commerce and recently served as Chairman of the Commission on Organization of the Executive Branch of the Government, never proposed a transfer of the ICC's regulatory powers to the Commerce Department. As Dr. Huntington indicates, Mr. Hoover's Commission was neither unfriendly to the Commerce Department nor notably sympathetic to the ICC. ${ }^{36}$

Quite apart from these objections to Dr. Huntington's proposal is a consideration which nowadays should receive increasing attention when governmental organization is under discussion. The danger to democratic institutions inherent in delegation of legislative power to the executive branch has become all too apparent in the last two decades. The sweeping delegations by the Reichstag to Chancellor Bruening paved the way for complete abdication to Hitler. Generally speaking, the greater the powers of the executive branch, the closer a government is to totalitarianism; the more active and critical the legislative body, the freer is speech and thought. Without meaning to inply, even remotely, that the transfer of the powers of the ICC to the Commerce Department would mean fascism, one cannot deny an instinctive sentiment that even the most minor accretion to executive power is to be avoided if at all possible.

31. Quoted in Morgan, stipra note 5, at 224.

32. Hearings before Subconmittee of Senate Committee on Appropriations, Dcpartments of State, Justice, and Conmerce and the Judiciary, Appropriations for 1953, 82d Cong., 2d Sess. 1445 (1952).

33. Id. at 1443; Hearings before Senate Committee on Interstate and Foreign Commerce on S. 2344, 82d Cong., 2d Sess. 109 (1952).

34. 16 FED. REG. 8189-90 (1951). Dr. Huntington paraphrased a part of this order in Huntington, pp. $469-70$ n.9, but he omitted the provision quoted above.

35. At the time of writing, the administration of Secretary Weeks had made no public statement on this subject.

36. Huntington, p. 475 . 


\section{The Proper Role of the Commerce Department in Transportation Regulation}

To express fear of executive expansion, however, is not to suggest that the present organization of transportation regulation is perfect. The writer's conclusion is, however, the reverse of Dr. Huntington's. The bodies which regulate shipping and aviation should, in the writer's opinion, be as free of any Commerce Department connection as the ICC. That the Federal Maritime Board is independent of the Secretary of Commerce in exercising regulatory functions has already been mentioned. Nevertheless, the Department is so actively engaged in maritime activities that the detachment essential to complete independence is difficult. When the writer presented the views of the Department to the Federal Maritime Board at an open hearing in a rate case, he could not escape the feeling that his arguments carried more weight than was warranted by the combined force of their intrinsic logic and the prestige inherent in any presentation by the executive branch. ${ }^{37}$ This intimacy between the Board and the Department follows from the provisions of Plan 21 that the Chairman of the Federal Maritime Board and the Maritime Administrator be the same person (Section 202), and that the Board and the Idministration shall make joint use of personnel (Section 302), together with the provision that the Maritime Administration and its Administrator are to be subordinate to the Secretary of Commerce (Sections 202 and 204). The theories supporting Board- 1 dministration affiliation are, according to the explanatory message of the President, that "cooperation" will be facilitated and that "many of the technical and professional personnel, such as ship designers and attorneys, now assist ... on problems of subsidy determination and also participate in the subsequent administration of subsidy agreements and in performing non-subsidy functions." 38 In this writer's observation the identities of office and personnel provided by Sections 202 and 302 tend to prevent that independence in regulatory functions provided by other parts of the Plan. As independence is of first importance, Sections 202 and 302 should be repealed, ${ }^{39}$ as well as that provision of Section 106 by which the Board is "an agency within the Department of Commerce."10

37. Yet, taking into account its responsibilities in the maritime ficld, the Department cannot be expected always to remain silent on important problems of maritime policy coming before the FMB.

38. H.R. Doc. No. 526, S1st Cong., $2 d$ Sess. 4 (1950).

39. Further, the burdens of Chairman of the Federal Maritime Board and Maritime Administrator are too great for one man.

40. On the other hand, it is only fair to say that maritime affairs were conducted in 1951 and 1952 with great efficiency and almost universal approval-the Comptroller General sounding the only discordant note. The writer attributes this success to factors other than any dominance of the FMB by the Department of Commerce by virtue of $\$ \$ 106,202$, and 302 of Plan 21 or otherwise. The FMB, headed by Vice-Admiral E. L. Cochrane, U.S.N. (ret.), who was also Mlaritime Administrator, was composed during these years of men of the highest qualifications. The Secretary of Cummerce admired and respected them. The Under Secretaries for Transportation had little or no maritime experience and were continually changing. It was rather Admiral Cochrane and his asso- 
The Civil Aeronautics Board is already independent, but that independence should be clarified. At present it is located on the fifth floor of the Commerce Building in Washington, the same floor with the Secretary and other Department officers. The Commerce Department supervises so-called "housekeeping" functions of the CAB. Presumably, these are the facts that have created an impression that the Department has some kind of authority over the Civil Aeronautics Board. ${ }^{41}$ The writer recommends that the Civil Aeronautics Board be given offices outside the Commerce Building and that its housekeeping functions be performed separately from those of the Commerce Department.

There is a useful role for the Department of Commerce in the formulation of transportation policy although not in the exercise of regulatory powers. The Department should be in the forefront in both drafting and analyzing proposed legislation, and in making cogent and forceful presentations in the more important cases before regulatory agencies. These types of activity have already been undertaken. For instance, the Department submitted elaborate and extensive comments on the so-called "Johnson bills," which were considered last year by the Senate Committee on Interstate and Foreign Commerce. ${ }^{42}$ These bills would have substantially revised the Interstate Com-

ciates who supplied policy to the Secretary-although obviously not in the form of commands-in both Board and Administration matters coming to his attention (with the exception of the Dollar Line settlement in which the Secretary took the lead). Although not accepting the judgments of these officials blindly, the Secretary trusted and supported them, and when occasion required, threw all his energy and the full weight of his office behind them. These circumstances combined to create for the FMB an independence far greater than would be the case if a Secretary, relying for advice on the Under Secretary for Transportation in accordance with the philosophy of Plan 21, chose to press on the FMB his views on regulation, subsidy, or other subjects. The writer doubts that the FMB could withstand such pressure. The evil, of course, would lie not in the presentation of his views by the Secretary, but in the possibility that the Board might not regard itsclf as entirely free to reject them.

By way of comparison with the views expressed in the text above, it should be noted that in informal discussions with the writer, Admiral Cochrane (now Dean of Engineering at the Massachusetts Institute of Technology) said that his experience had led him to conclude that the present arrangement should be retained. He believed that, the Maritime Administration rightly being in the Department of Commerce, the FMB should be there too, because their tasks are so closely related. Despite his great regard for Admiral Cochrane's acumen, the writer questions whether Admiral Cochrane's conclusion would have been the same if he had found in the Secretary a commander, instead of a confidant and champion, available when needed.

41. See comments of Senator Bridges at Hearings before Subcommittce of Schatc Comnnittee on Appropriations, Departments of State, Justice, and Commerce and thi Judiciary, Appropriations for 1953, 82d Cong., 2d Sess. 1445 (1952). "Housekeeping" consists of "budget, accounting, personnel, procurement and related routine mantagement functions." $\S 7$ (c), Reorganization Plan No. 4 of 1939, 53 Stat. 562 (1939), 5 U.S.C. $\$ 139$ (1946).

42. Hearings before the Committee on Interstate and Forcign Conmerce an Bills relating to Domestic Land and Water Transportation, 82d Cong., 2d Sess. (1952). The writer's testimony on behalf of the Department appears $i d$. at 39 and passim. 
merce Act. The Department itself regularly proposes transportation bills. These. fairly technical in character, have originated in the bureaus, but it may be anticipated that the Under Secretary for Transportation vill soon submit bills relating to over-all policy. The Department has participated in a number of important cases before the regulatory agencies since the adoption of Plan $21^{43}$ and might well be more active in the future. Congressional uncertainty as to the wisdom of appearances by the Department before the Civil Aeronautics Board has apparently been based on confusion concerning the relationship between the two agencies. ${ }^{44}$ But Congress regularly invites the Department to express its views on transportation policies before legislative committees. Thus, Congress could hardly object if the Department made similar presentations to the delegates of Congress: the regulatory agencies. In this way the executive branch would be assured a proper status in transportation policy-a regular and orderly opportunity to be heard whenever important questions are being determined. ${ }^{45}$

This course would tend to fill another need in transportation regulation. From time to time, sentiment has been expressed for an organization to harmonize decisions of the ICC, FNB, and CAB, and an enterprising gentleman under the auspices of the United States Chamber of Commerce has already drafted the organizational chart of a super-commission to accomplish this re-

43. Ex parte 175, 280 I.C.C. 179 (1951), 281 I.C.C. 557 (1051), 2⿰氵4 I.C.C. 539 (1952); The North Atlantic Cortificati Rencial Case, decilsd by the CAE, March 27. 1952, not yet oficially reported: The Irrimlar Curricr Inastigation (CAB); The United States-Atlantic-Middle East Air Cargo Case (CAB); Goneral Order io (FMB); and The North Atlantic Confercnee Rates Case (FMIB). The Department's intervention in Ex parte 175 was not to express its views but to malie availatle to the Commission the resources of its Office of Transportation and Ofice of Eusiness Economics as a check on the data and estimates submitted by the railresds. The ICC placed great reliance on the Department's evidence. 284 I.C.C. $\$ \$ 9,600$ at sig., $622 \mathrm{dt} 5 \mathrm{~s}$. Fvon President Franlilin of the Pennsylvania Railroad, a stern critic of guvernment intervention in rate cases, conceded that the Department's estimates were "exccptionally gơd." Hearings, supra note 42 , at $\mathbb{S} 3$.

44. See note 41 supra.

45. Objection has been made. notably by Mr. Franllin, to aiy appearanse by guvernment departments in ICC cases, principally on the ground that it is time-consuming. Apparently Dr. Morgan to some extent sympathizes with his objection. MLrgan, sufro note 5, at 211-12. There has undoubtedly bein duplication of effort and waste oi time in such appearances, although these evils were finally currectcd in so elatirate a proceeding as Ex parte 175, 284 I.C.C. $5 \$ 9$ (1952). Sce the Commissiun's comment, id. at 627-8. Whatever the pros and cons of these abuses, and they are not unawidatle, the proposition can hardly be seriously maintained that if the executive branch wants to present some evidence or argument to a regulatory agency in an open hearing and in accordance with the agency's rules of procedure, it should nut be permittcd to do so. And in view of the importance of transportation. interventions by the exccutize branch are to be expected occasionally. The frequency of such ocearins mut 1 : l.fit the th: sound discretion of the executive branch. As already mentiund, strisaraiss by the Department of Commerce before the FMIB raise a different problem, which would $\mathrm{l}$ : solved by breaking the links between them. 
sult. ${ }^{46}$ But one trembles at the thought of another bureaucracy. The Department of Commerce is perhaps the only organization, public or private, that has occasion to appear with some frequency before all three of these agencies in important policy cases. The Department might well, whenever relevant, call to the attention of each body the principles and concepts adopted by the others. In this way there would be exerted a certain pressure in favor of consistency. This is probably as far as it is desirable to go. There is such a thing as too much consistency. If, and this is only an assumption, the agencies should persist in irreconcilable attitudes not warranted by the differences in the industries subject to their regulation, Congress may be expected to provide relief.

In conclusion, then, the transfer to the Department of Commerce of the regulatory powers of the ICC must be rejected. Whatever the vices of the present arrangement, such a transfer would unnecessarily violate the concept of the separation of powers and would bestow authority on an agency without experience in or qualification for its exercise. The very proper interest of the executive branch in transportation policy can best be expressed by persuasive presentations by the Department to Congress and to the regulatory agencies.

46. Traffic World, Dec. 22, 1951, p. 24. 


\section{THE YALE LAW JOURNAL}

\section{EDITORIAL BOARD \\ ERTEst Rugenstem Editor-in-Chief}

Annold M. Lersasi

WILlinar R. MIURPHY

Executive Editors

Williatar 11. BRAdNer

ANDREW C. HARTZELL, JR.

StUART C. LAW

STUART RoBinOwITZ

H. RICHARD UYHLIER

Note and Connment Editors
Jomn G. Snrox

Article and

Book Review Editor
Grorge Beristein

Theron L. Caunle, JR Peter S. Craig

William A. Descano

Kraus DoHNanyi
JoHN D. FAsSETT

Charles E. Frases

Arthus B. Fsodiries

Alice B. Gilleert

ANDREw D. Hemenan, Bus. JIgr.
JoHN W. Frossurs, Js. Case Editor

Cenrues R Bercofre:

MAURICE N. Nesser: Maraging Editors

I:I2n:TUEx Köm

Ruchand I. A. Keto:i

Lgotiano Mr. Polisar:

JEROAIE S. WAGSEAL

Editor in Military Sercice

BarRy H. GARFinKEt, Managing Edilor

MLARIE MICMAHON

Business Secretary

\section{CONTRIBUTORS TO THIS ISSUE}

HARRY LeRoy Jones. B.A. 1916, Indiana University; LL.B. 1922, Northwestern University. Lecturer, Northwestern University Law School, 1923-6. Formerly Chief Attorney, Alien Property Bureau, and Chief, Alien Property Litigation Section, Department of Justice. Advisor on Judicial Assistance, Harvard Research on International Law, 1938. Chairman, Committee on International Judicial Cooperation, Section of International and Comparative Law, American Bar Association, and of committee of same name, International Bar Association. Member, Illinois and District of Columbia Bars. Chief Hearing Examiner, Office of Alien Property, Department of Justice.

C. Dickerasan Whitanss. B.A. 1922, LL.B. 1924, Yale University. Editor-in-Chiuf, Yale LAw Journal, 1923-4. General Counsel, United States Department of Commerce, 1951-January, 1953. Member, New York Bar. 